\title{
KAJIAN TENTANG PENGGUNAAN ALAT BUKTI PETUNJUK OLEH JAKSA PENUNTUT UMUM DALAM PERKARA PENCABULAN ANAK
}

\author{
Pityani Meutia Lubis \\ Kantor Wilayah Kementerian Hukum dan Hak Asasi Manusia Sumatera Utara \\ Jl. Putri Hijau No. 4, Medan - Sumatera Utara. \\ Email: pityanimeutialubis@gmail.com
}

\begin{abstract}
Abstrak
Petunjuk digunakan untuk meningkatkan kepercayaan hakim bahwa terdakwa bersalah atau tidak. Instruksi yang diperoleh dari pernyataan saksi, surat dan dari pernyataan terdakwa disatukan, kemudian disatukan dan akan membuat petunjuk yang dapat memperkuat keyakinan hakim bahwa terdakwa bersalah atau tidak. Tidak hanya itu, bukti seperti sperma ditemukan di sekitar vagina korban, kerusakan pada selaput darah (selaput dara) dan celana dalam korban juga alat untuk memperkuat bukti untuk membuktikan bahwa korban telah memperkosa dirinya sendiri. Kecil kemungkinan bahwa laporan perkosaan akan terjadi setelah beberapa hari setelah kejadian, karena dikhawatirkan bukti yang diperlukan akan lemah atau tidak lagi terlihat, sehingga membuat hakim sulit untuk percaya bahwa perkosaan telah terjadi. Tulisan ini menggunakan metode penelitian hukum yuridis normatif (penelitian normatif) dengan spesifikasi penelitian deskriptif analitik yang menggunakan data sekunder. Prosedur pengumpulan data adalah dalam bentuk dokumentasi catatan atau kutipan, pencarian literatur hukum, buku-buku dan lain-lain yang berkaitan dengan identifikasi masalah baik offline maupun online, yang kemudian dianalisis melalui metode analisis konten (content analysis method) dengan fokus pada masalah tentang bagaimana dasar hukum penggunaan bukti dari Jaksa Penuntut Umum sebagai sarana pembuktian kasus pelecehan anak, bagaimana proses penggunaan bukti dari Jaksa Penuntut Umum sebagai alat pembuktian kasus pelecehan seksual terhadap anak-anak.
\end{abstract}

\section{Kata Kunci: Petunjuk, Bukti, Jaksa, Pencabulan, Anak}

\section{Abstract}

An indication is used to increase the judge's confidence that the accused is guilty or not. Instructions obtained from witness statements, letters and from the defendant's statement were put together, then put together and will make a clue that can strengthen the judge's conviction that the defendant is guilty or not. Not only that, evidence such as sperm found around the victim's vagina, damage to the blood membrane (hymen) and the victim's panties are also tools to strengthen evidence to prove that the victim has raped herself. It is unlikely that reports of rape will occur after a few days after the incident, because it is feared that the necessary evidence will be weak or no longer visible, making it difficult for the judge to believe that rape has occurred. This writing uses normative juridical legal research methods (normative research) with descriptive analytical research specifications that use secondary data. The procedure of data collection is in the form of documentation of notes or quotations, search of legal literature, books and others related to the identification of problems both offline and online, which are then analyzed through the content analysis method (content 
DE LEGA LATA

Jurnal Ilmu Hukum

FAKULTAS HUKUM UMSU
Kajian Tentang Penggunaan...(Pityani Meutia Lubis)

Volume 3 Nomor 2, Juli-Desember 2018, 185-203 DOI: https://doi.org/10.30596/dll.v3i2.3159

analysis method) with a focus on issues about how the legal basis the use of evidence from the Public Prosecutor as a means of proving the case of molestation of children, how is the process of using evidence from the Public Prosecutor as a means of proof of sexual abuse cases against children.

\section{Keywords: Instructions, Evidence, Prosecutors, Revocation, Children}

\section{PENDAHULUAN}

Hukum adalah kumpulan dari berbagai aturan-aturan hidup (tertulis atau tidak tertulis), yang menentukan apakah yang patut dan tidak patut dilakukan oleh seseorang dalam pergaulan hidupnya, suatu hal yang khusus yang terdapat pada peraturan-peraturan hidup itu, yakni bahwa untuk pentaatannya ketentuan itu dapat dipaksakan berlakunya (Soedjono Dirdjosisworo, 1983, h. 10).

Hukum sebagai suatu sistem dapat berperan dengan baik dan benar di tengah masyarakat jika instrumen pelaksanaanya dilengkapi kewenangan-kewenangan dalam bidang penegakan hukum. Untuk mewujudkan prinsip-prinsip negara hukum, diperlukan baik normanorma hukum atau peraturan perundang-undangan, juga aparatur pengemban dan penegak hukum yang profesional, berintegritas, dan disiplin yang didukung oleh sarana dan prasarana hukum serta perilaku hukum masyarakat.

Salah satu institusi penegak hukum yang mempunyai kedudukan yang sentral dan peranan strategis adalah kejaksaan. Karena institusi ini menjadi filter antara proses penyidikan dan proses pemeriksaan di persidangan. Keberadaan Jaksa yang mempunyai kewenangan dalam penuntutan dan pelaksana putusan pengadilan yang telah memiliki kekuatan hukum tetap serta wewenang lain berdasar undang-undang diharapkan mampu menjalankan tugasnya secara profesional dan berdedikasi menciptakan keadilan dalam penegakan hukum.

Adapun dalam membuktikan perkara pidana jaksa penuntut umum dituntut menggunakan alat bukti yang telah diatur dalam Kitab Undang-Undang Hukum Acara Pidana (KUHAP). Alat bukti yang digunakan seperti dalam rumusan Pasal 184 KUHAP berupa keterangan saksi, keterangan ahli, surat, petunjuk dan keterangan terdakwa. Proses pembuktian oleh Jaksa Penuntut Umum sebagian terkendala minimnya bukti-bukti yang dihadirkan dalam persidangan. Maka, Jaksa Penuntut Umum menggunakan alat bukti petunjuk dalam pemeriksaan pembuktian sebagaimana dirumuskan dalam Pasal 188 ayat (1) KUHAP yaitu "Petunjuk adalah perbuatan, kejadian atau keadaan yang karena persesuainnya, baik antar satu dengan lainnya maupun dengan tindak pidana itu sendiri menandakan telah terjadi suatu tindak pidana dan siapa pelakunya".

R. Sughandhi menguraikan tentang pencabulan yaitu:

Seorang pria yang memaksa pada seorang wanita bukan isterinya untuk melakukan persetubuhan dengannya dengan ancaman kekerasan, yang mana diharuskan kemaluan pria telah masuk ke dalam lubang kemaluan seorang wanita yang kemudian mengeluarkan air mani (P.A.F. Lamintang, 1997, h. 41). 
DE LEGA LATA

Jurnal Ilmu Hukum

FAKULTAS HUKUM UMSU
Kajian Tentang Penggunaan...(Pityani Meutia Lubis)

Volume 3 Nomor 2, Juli-Desember 2018, 185-203 DOI: https://doi.org/10.30596/dll.v3i2.3159

Karakteristik utama dalam perkosaan ialah "bahwa perkosaan terutama bukan ekspresi agrsivitas (baca: kekerasan) dari seksualitas (the agressive expression of sexuality) akan tetapi merupakan ekspresi seksual dari suatu agresivitas (sexual expression of aggression) (Romli Atmasasmita, 1995, h. 108). Alat bukti petunjuk baru benar-benar digunakan Jaksa Penuntut Umum sebagai dasar membuat tuntutan apabila batas minimum pembuktian belum tercapai. Alat Bukti yang dihadirkan dalam persidangan sebagian besar kurang memenuhi persyaratan untuk membuktikan kesalahan terdakwa. Pembuktian dalam perkara pencabulan adalah salah satu dari beberapa perkara yang menggunakan alat bukti petunjuk dalam pembuktiannya. Dalam pembuktian kasus-kasus pencabulan, Jaksa Penuntut Umum sering mengalami kesulitan yang umumnya terjadi karena tidak ada saksi selain pelaku dan korban pencabulan itu sendiri.

Selain itu kurangnya alat bukti sebagai kunci kasus pencabulan mengakibatkan sistem pembuktian oleh jaksa menjadi mengambang. Hal tersebut makin diperparah dengan kondisi psikologis korban pencabulan yang kebanyakan tidak melaporkan dan tidak berani memaparkan kejadian yang sebenarnya akibat dari ketakutan dan trauma yang berlebihan menjadikan proses pembuktian semakin sulit. Meskipun demikian upaya pembuktian oleh jaksa penuntut umum berkaitan dengan bahwa korban pencabulan harus tetap diikuti dengan bukti-bukti terdapatnya tanda-tanda kekerasan, seperti luka pada bagian tubuh tertentu. Karena bagaimanapun juga substansi yuridis dalam KUHP tidak mencantumkan unsur-unsur, akibat-akibat yang timbul karena perkosaan seperti kehamilan, trauma psikologis, dan trauma secara fisik tentunya.

Kejahatan seksual yang diatur dalam Pasal 285 KUHP ini ternyata tidak hanya dialami oleh perempuan dewasa akan tetapi juga menimpa anak perempuan. Hal yang lebih memprihatinkan lagi adalah makin maraknya tindak pidana ini justru juga dilakukan oleh anak-anak. Substansi hukum dari perumusan Pasal 285 KUHP ini terkendala dalam menjatuhkan pidana terhadap pelaku. Hal tersebut berkaitan dengan konsekuensi hukum mengenai penjatuhan pidana terhadap pelaku yang termasuk anak. Apabila penjatuhan pidana anak disamakan dengan pelaku dewasa sesuai KUHP muncul sudut pandang yang berbeda meskipun pelaku sama-sama melakukan tindak pencabulan. Karena kebutuhan hukum itulah atau lebih tepatnya sebagai pendekatan hukum pidana secara esensial maka orientasi pelaku lebih komplek diatur dalam Pasal 81 ayat 1 Undang-Undang Nomor 35 Tahun 2014 Perubahan Atas Undang-Undang Nomor 23 Tahun 2002 Tentang Perlindungan Anak.

Tindak pidana pencabulan merupakan kasus yang kasuistis, maksudnya tindak pidana pencabulan hanya dapat dibuktikan dengan alat bukti dan barang bukti bahwa tindak pidana tersebut telah terjadi. Dalam membuktikan telah terjadi atau belumnya tindak pidana pencabulan sering mengalami kesulitan. Kesulitan yang dimaksud dalam hal ini yaitu tidak terdapatnya saksi yang melihat langsung kejadian kecuali anak korban dan terdakwa saja, serta terdakwa tidak mau mengakui bahwa kejadian tersebut tidak ia lakukan atau terdakwa 
DE LEGA LATA

Jurnal Ilmu Hukum

FAKULTAS HUKUM UMSU
Kajian Tentang Penggunaan...(Pityani Meutia Lubis)

Volume 3 Nomor 2, Juli-Desember 2018, 185-203 DOI: https://doi.org/10.30596/dll.v3i2.3159

selalu berkelik bahwa perbuatan tersebut dilakukan atas dasar suka-sama suka. Dalam hal ini hakim akan sangat sulit untuk membuktikan dan memutus perkara tersebut.

Alat bukti petunjuk digunakan untuk menambah keyakinan hakim bahwa terdakwa bersalah atau tidak. Petunjuk diperoleh dari keterangan saksi, surat serta dari keterangan terdakwa yang dijadikan satu, kemudian disatukan dan akan membuat satu petunjuk yang dapat menguatkan keyakinan hakim bahwa terdakwa bersalah atau tidak. Tidak hanya itu, bukti seperti sperma yang terdapat disekitar vagina korban, rusaknya selaput darah (hymen) dan celana dalam korban juga menjadi alat bukti petunjuk yang menguatkan untuk membuktikan telah terjadi pemerkosaan pada diri si korban. Kecil kemungkinan apabila laporan mengenai terjadinya pemerkosaan dilakukan setelah beberapa hari setelah kejadian, karena ditakutkan bukti-bukti yang diperlukan menjadi lemah atau tidak tampak lagi sehingga sulit bagi hakim untuk percaya bahwa telah terjadi perkosaan.

Mengenai alat bukti petunjuk sebagai sarana pembuktian oleh jaksa penuntut umum terhadap perkara pencabulan anak, sehingga yang menjadi fokus permasalahan dalam penulisan ini adalah Bagaimana dasar hukum penggunaan alat bukti petunjuk oleh Jaksa Penuntut Umum (JPU) sebagai sarana pembuktian perkara pencabulan terhadap anak?, Bagaimana proses penggunaan alat bukti petunjuk oleh Jaksa Penuntut Umum sebagai sarana pembuktian perkara pencabulan terhadap anak? dengan harapan tulisan ini dapat bermanfaat baik secara teori maupun praktis bagi khalayak luas mengenai alat bukti petunjuk sebagai sarana pembuktian oleh jaksa penuntut umum terhadap perkara pencabulan anak.

\section{METODE PENELITIAN}

Penulisan ini menggunakan metode penelitian hukum yuridis normatif (normatif research), yaitu penelitian hukum yang dilakukan dengan cara meneliti bahan pustaka atau data skunder (Seokanto dan Sri Muji, 2003, h. 15). Spesifikasi penelitian dalam penulisan ini berupa penelitian deskriptif analistis. Deskriptif adalah menunjukan komparasi atau hubungan seperangkat data dengan seperangkat data yang lain, dan maksudnya adalah untuk memberikan gambaran, menelaah, menjelaskan dan menganalisis (Soekanto, 1996, h. 63).

Sesuai jenis dan sifat penelitiannya, maka sumber data yang digunakan dalam penulisan ini adalah data skunder yang terdiri dari bahan hukum primer berupa; Kitab Undang-undang Hukum Pidana (KUHP) Undang-Undang Nomor 8 Tahun 1981 tentang Hukum Acara Pidana (KUHAP), Putusan Mahkamah Agung tanggal 17-4-1987, No 28 K/Kr./1977. Bahan hukum sekunder terdiri dari buku-buku, jurnal ilmiah, makalah dan artikel ilmiah yang dapat memberi penjelasan tentang bahan hukum primer. Bahan hukum tersier; berupa Kamus Besar Bahasa Indonesia (KBBI) dan lain sebagainya dalam menemukan defenisi dari istilah-istilah dalam membahas mengenai alat bukti petunjuk sebagai sarana pembuktian oleh jaksa penuntut umum terhadap perkara pencabulan anak.

Prosedur yang digunakan untuk mengumpulkan data dalam penilitian ini berupa 
DE LEGA LATA

Jurnal Ilmu Hukum

FAKULTAS HUKUM UMSU
Kajian Tentang Penggunaan...(Pityani Meutia Lubis)

Volume 3 Nomor 2, Juli-Desember 2018, 185-203 DOI: https://doi.org/10.30596/dll.v3i2.3159

dokumentasi yaitu pedoman yang digunakan berupa catatan atau kutipan, penelusuran literatur hukum, buku-buku dan lainnya yang bertalian dengan identifikasi masalah dalam penilitian ini dengan cara offline maupun online. Analisa bahan hukum dilakukan dengan menggunakan metode analisa konten (centent analysis method) yang dilakukan dengan menguraikan materi peristiwa hukum atau produk hukum secara rinci guna memudahkan interpretasi dalam pembahasan (Marzuki, 2011, h. 171). Penelitian ini ditujukan untuk mencari jawaban bagaimana dasar hukum penggunaan alat bukti petunjuk oleh Jaksa Penuntut Umum sebagai sarana pembuktian perkara pencabulan terhadap anak, dan bagaimana proses penggunaan alat bukti petunjuk oleh Jaksa Penuntut Umum sebagai sarana pembuktian perkara pencabulan terhadap anak.

\section{PEMBAHASAN}

\section{Dasar Hukum Penggunaan Alat Bukti Petunjuk Oleh Jaksa Penuntut Umum Sebagai Sarana Pembuktian Perkara Pencabulan Terhadap Anak}

\section{Kedudukan Alat Bukti Petunjuk dalam Proses Penyidikan}

Menurut D. Simons sebagaimana dikutip dalam bukunya Andi Hamzah, menyatakan sebagai berikut, "Sistem hakim yang tetap di Indonesia mengikuti sistem di Negara Belanda yang dahulu juga menganut sistem juri pula, tetapi sejak tahun 1813 dihapuskan”. Sebaliknya Perancis sejak revolusi meniru sistem itu dari Inggris. Karena banyaknya kelemahankelemahan sistem tersebut maka Jerman juga tidak menganutnya (M Yahya Harahap, 2001, h. 22).

Tidak ada perkara pidana yang luput dari pembuktian alat bukti keterangan saksi. Hampir semua pembuktian perkara pidana, selalu bersandar pada pemeriksaan keterangan saksi.Sekurang-kurangnya di samping pembuktian dengan alat bukti yanglain, masih selalu diperlukan pembuktian dengan alat bukti keterangansaksi (Yahya Harahap, 2007, h. 286). Ketentuan dalam Pasal 188 ayat 1 KUHAP menyebutkan bahwa petunjuk adalah "perbuatan, kejadian atau keadaan yang karena persesuaiannya, baik antara yang satu dengan yang lain, maupun dengan tindak pidana itu sendiri, menandakan bahwa telah terjadi suatu tindak pidana dan siapa pelakunya" (Andi Hamzah, 2014, h. 277). Yang dimaksud dengan petunjukpetunjuk adalah perbuatan-perbuatan, kejadian-kejadian atau hal-hal yang ada persesuaiannya baik satu sama lain maupun dengan perbuatan yang dituduhkan terhadap terdakwa dapat menunjukkan dengan nyata bahwa suatu kejahatan telah dilakukan dan siapa yang melakukannya.

Adapun yang dimaksud dengan petunjuk-petunjuk adalah perbuatan-perbuataan, kejadian-kejadian atau hal-hal yang ada persesuaiannya baik satu sama lain maupun dengan perbuatan yang dituduhkan terhadap terdakwa dapat menunjukkan dengan nyata bahwa suatu kejahatan telah dilakukan dan siapa yang melakukannya (Pasal 188 KUHAP). Menurut Pasal 188 ayat 2 KUHAP adanya petunjuk hanya dapat dibuktikan oleh: 
Kajian Tentang Penggunaan...(Pityani Meutia Lubis) DOI: https://doi.org/10.30596/dll.v3i2.3159
a. Saksi-saksi
b. Surat-surat
c. Pemeriksaan sendiri ataupun penyaksian oleh hakim
d. Pengakuan sendiri oleh tertuduh biarpun tidak dilakukan dimuka hakim.

Apabila diperhatikan bahwa Pasal 188 ayat 1 KUHAP tersebut mengandung maksud bahwa tidak ada kepastian yang mutlak bagi terdakwa yang benar-benar telah bersalah melakukan perbuatan sebagaimana yang didakwakan. Oleh karena itu perbuatan, kejadian atau keadaan baru dianggap sebagai petunjuk apabila ada persesuaaian baik antara satu dengan yang lain, maupun tindak pidana itu sendiri, yang menandakan bahwa telah terjadi suatu tindak pidana dan siapa pelaku tindak pidana tersebut. Dengan alat bukti petunjuk dapat dinilai mempunyai kekuatan sebagai alat bukti yang sah, selain itu alat bukti petunjuk baru mempunyai kekuatan sebagai alat bukti yang sah apabila ada persesuaian yang diperoleh dari keterangan saksi, surat dan keterangan terdakwa sebagaimana pada Pasal 188 ayat 2 KUHAP.

Petunjuk dapat berupa sebuah keterangan, namun tidak semua keterangan itu dapat dijadikan petunjuk. Keterangan yang diperoleh dari seorang saksi bisa disebut sebagai petunjuk, akan tetapi apabila keterangan itu diperoleh dari tersangka maupun terdakwa bukanlah petunjuk tetapi bisa menjadi keterangan yang akan memberatkan (A charge) ataupun sebaliknya keterangannya itu dapat meringankan (A de charge).

Selain itu petunjuk dapat diperoleh dari barang bukti, meskipun keberadaan barang bukti ini bukan merupakan alat bukti. Yang mana barang bukti hanya ada di "bukti permulaan yang cukup", yaitu bukti yang berupa keterangan-keterangan dan data yang terkandung dalam:

a. Laporan Polisi;

b. BAP saksi /tersangka (BAP TKP);

c. Pelaporan hasil penyelidikan;

d. Barang Bukti.

Alat bukti petunjuk pengertiannya dapat dilihat menurut KUHAP Pasal 188 ayat 1. Berbicara tentang alat bukti petunjuk itu sendiri mengenai pengertiannya dapat dilihat menurut KUHAP Pasal 188 Ayat 1 "Petunjuk adalah perbuatan, kejadian atau keadaan, yang karena persesuaiannya, baik antara yang satu dengan yang lain, maupun dengan tindak pidana itu sendiri, menandakan telah terjadi suatu tindak pidana dan siapa pelakunya." Menurut M. Yahya Harahap yaitu:

Petunjuk ialah suatu isyarat yang dapat ditarik dari suatu perbuatan, kejadian atau keadaan dimana isyarat itu mempunyai persesuaian antara yang satu dengan yang lain maupun isyarat itu mempunyai persesuaian dengan tindak pidana itu sendiri, dan dari isyarat yang bersesuaian tersebut melahirkan atau mewujudkan suatu petunjuk yang membentuk kenyataan terjadinya suatu tindak pidana dan terdakwalah pelakunya (M. Yahya Harahap, 2018, h. 313). 
Jurnal Ilmu Hukum

FAKULTAS HUKUM UMSU
Käjan Tentang Penggunaan...(Pityani Meutia Lubis) DOI: https://doi.org/10.30596/dll.v3i2.3159

Untuk memperkuat proses pembuktian perkara pidana yang dilakukan dalam persidangan sesuai dengan pengertian alat bukti petunjuk, peran dan fungsi alat bukti petunjuk itu sama dengan alat bukti yang lain dalam KUHAP yaitu. Akan tetapi alat bukti petunjuk ini baru dipakai apabila dirasa dari alat bukti-alat bukti yang lain masih kurang untuk dilakukan pembuktian atas kesalahan terdakwa ataupun dari alat-alat bukti yang ada masih belum cukup atau tidak ada persesuaian diantaranya.

Peran dan fungsi dari alat bukti petunjuk ini untuk membuat terang suatu perkara apakah benar-benar terjadi tindak pidana. Suatu ketika surat Berita Acara Pemeriksaan oleh penyidik yang dilimpahkan ke kejaksaan belum lengkap dan belum bisa mencukupi pembuktian maka diberilah petunjuk untuk menemukan persesuaiannya.

Setelah alat bukti yang bersesuaian yaitu minimal 2 (dua) alat bukti didapat dalam perkara yang dilakukan maka alat Bukti Petunjuk dapat mengambil perannya. Contohnya ada saksi yang diperiksa dengan tidak disumpah, tetapi keterangannya bersesuaian satu sama lain. Jadi keterangan itu bisa ditarik sebagai petunjuk/digunakan sebagai petunjuk. Pada praktiknya alat bukti petunjuk tidak selalu digunakan dalam pembuktian perkara pidana, tetapi banyak digunakan oleh hakim dalam hal memperkuat dan mempertebal keyakinannya. Alat bukti petunjuk digunakan manakala alat bukti yang lain (surat, keterangan saksi, keterangan terdakwa) masih belum menguatkan keyakinan hakim. Sehingga dengan adanya alat bukti petunjuk akan lebih mempertebal keyakinan hakim bahwa benar telah terjadi tindak pidana dan terdakwa tersebut benar sebagai pelakunya.

Uraian di atas sudah cukup jelas menjabarkan tentang bagaimana peran dan fungsi dari alat bukti petunjuk yang merupakan salah satu alat bukti yang sah dalam KUHAP, secara singkat dikatakan bahwa peran dan fungsi alat bukti petunjuk adalah memperkuat proses pembuktian perkara pidana, selain itu juga dalam persidangan untuk memperkuat atau mempertebal keyakinan hakim dalam memeriksa dan memutus perkara.

Apabila kita mengiku aturan mengenai rumusan tentang pengertian alat bukti petunjuk dalam Pasal 188 ayat 1 dan ayat 2, maka unsur atau syarat alat bukti petunjuk adalah:

a. Unsur pertama, adanya perbuatan, kejadian, keadaan yang bersesuaian;

b. Unsur kedua, ada 2 (dua) persesuaian, ialah;

1) Bersesuaian antara masingmasing perbuatan, kejadian dan keadaan satu dengan yang lain, maupun

2) Bersesuaian antara perbuatan, kejadian, dan atau keadaan dengan tindak pidana yang didakwakan;

c. Unsur ketiga, dengan adanya persesuaian yang demikian itu menandakan (menjadi suatu tanda) atau menunjukkan adanya 2 (dua) hal in casu kejadian, ialah:

1) Pertama, menunjukkan bahwa benar telah terjadi suatu tindak pidana, dan

2) Kedua, menunjukkan siapa pembuatnya.

d. Alat bukti petunjuk hanya dapat dibentuk melalui 3 alat bukti, yaitu keterangan saksi, surat dan keterangan terdakwa. 
DE LEGA LATA

Jurnal Ilmu Hukum

FAKULTAS HUKUM UMSU
Kajian Tentang Penggunaan...(Pityani Meutia Lubis)

Volume 3 Nomor 2, Juli-Desember 2018, 185-203 DOI: https://doi.org/10.30596/dll.v3i2.3159

Ketentuan Pasal 188 ayat 2 adalah harus didapat dari 3 (tiga) alat bukti yaitu: keterangan saksi, surat dan keterangan terdakwa. Menurut hemat penulis didapat dari dua alat bukti baik jenis yang sama maupun jenis yang berlainan diantara tiga alat bukti tersebut sudahlah cukup. Merujuk pasal tersebut di atas bahwa ada dua bagian persesuaian, yakni:

a. Persesuaian yang pertama, adalah persesuaian antara masing-masing perbuatan, antara masing-masing keadaan, antara masing-masing kejadian atau terhadap yang satu dengan yang lainnya. Artinya, fakta-fakta tentang perbuatan, kejadian dan keadaan yang diperoleh dari dua atau lebih alat bukti keterangan saksi, keterangan terdakwa, dan atau surat, walaupun berbeda-beda, masing-masing ada hubungan yang erat, atau dapat dihubungkan. Hubungannya itu bersifat saling melengkapi, saling menunjang antara satu terhadap lainnya, sehingga dapat ditarik suatu kesimpulan (petunjuk) bahwa benar telah terjadi tindak pidana dan terdakwa bersalah melakukannya.

b. Persesuaian yang kedua, adalah persesuaian antara perbuatan, kejadian atau keadaan dengan tindak pidana yang didakwakan. Setiap tindak pidana mengandung unsur-unsur. Kompleksitas unsur-unsur itulah yang dinamakan tindak pidana. Oleh karena itu, persesuaian dengan tindak pidana tersebut adalah bersesuaian dengan unsur-unsur yang ada, walaupun mungkin isi dari suatu alat bukti yang bersesuaian dengan sebagian unsur saja. Namun, dari persesuaian alat bukti ini dan isi dari alat bukti lainnya harus dapat menunjukkan (dapat disimpulkan) secara akal telah terjadi suatu tindak pidana dan siapa pembuatnya. Dua persesuaian itu sifatnya kumulatif dan impertatif. Artinya, tidak cukup satu persesuaian saja, namun harus kedua-dua persesuaian.

Adanya persesuaian yang menandakan adanya 2 (dua) hal kejadian atau keadaan, ialah bahwa (1) Benar Telah Terjadi Suatu Tindak Pidana, dan (2) Menunjukkan Siapa Pembuatnya. Alat Bukti Petunjuk Hanya Dapat Dibentuk dengan Menggunakan Keterangan Saksi, Surat dan Keterangan Terdakwa. Apakah ketiga alat bukti itu harus bekerja bersama untuk menghasilkan alat bukti petunjuk? Tidak ada keterangan yang mengharuskan menggunakan ketiga-tiganya, Walaupun Pasal 183 mengenai syarat minimal pembuktian itu ditujukan dalam hal hakim membentuk keyakinannya untuk menjatuhkan pidana. Namun, tidaklah salah apabila minimal dua alat bukti itu ditafsirkan berlaku pula dalam hal membentuk alat bukti petunjuk, karena ketentuan Pasal 183 adalah merupakan asasnya. Seperti juga pada salah satu syarat untuk sah dan bernilainya keterangan saksi (Pasal 185 ayat (2), ialah harus didukung oleh alat bukti lainnya. Demikian juga mengenai keterangan terdakwa yang harus didukung oleh alat bukti lainnya (Pasal 189 ayat 4). Asas minimal dua alat bukti tercermin dalam Pasal 185 ayat 2 dan Pasal 189 ayat 4 tersebut.

Berdasarkan pada jiwa dari Pasal 183 tersebut diatas, maka alat bukti petunjuk telah dapat dibentuk oleh hakim melalui dua alat bukti yang disebutkan dalam Pasal 188 ayat 2, baik dalam jenis yang sama maupun dalam jenis yang berbeda. Yang penting alat bukti petunjuk harus dibentuk melalui minimal dari 2 (dua) alat bukti yang telah dipergunakan 
DE LEGA LATA

Jurnal Ilmu Hukum

FAKULTAS HUKUM UMSU
Kajian Tentang Penggunaan...(Pityani Meutia Lubis)

Volume 3 Nomor 2, Juli-Desember 2018, 185-203 DOI: https://doi.org/10.30596/dll.v3i2.3159

dalam sidang-sidang sebelumnya. Alat bukti petunjuk hanya bisa dibentuk oleh hakim se telah memeriksa alat-alat bukti, bahkan semua alat bukti. Artinya, alat bukti petunjuk ini hanya dibentuk hakim melalui pertimbangan hokum dalam putusan. Demikian maksud dari alat bukti petunjuk.

Jaksa penuntut umum boleh menggunakan alat bukti petunjuk. Jaksa membentuk alat bukti petunjuk adalah dalam requisitoirnya dan penasihat hukum akan menyangkal bentukan alat bukti petunjuk jaksa dalam pleidoinya. Akan tetapi, alat bukti petunjuk hasil bentukan jaksa penuntut umum dan atau bantahan penasihat hukum, tidaklah mengikat hakim

Pembuktian alat bukti petunjuk bentukan jaksa penuntut umum, bagi hakim nilai pembuktiannya adalah bebas. Bernilai bebas nilainya bergantung kepada hakim, apakah mengandung nilai dan akan dipergunakan sebagai alat bukti petunjuk dalam pertimbangan hukumnya ataukah diabaikan saja, sepenuhnya bergantung kepada hakim sendiri. Namun, sebagai jaksa yang baik menjadi beban tugasnya untuk berusaha membentuk alat bukti petunjuk. Demikian juga bagi penasihat hukum yang baik dan profesional, tentu menjadi kewajiban profesinya untuk menyangkal atau mementahkan alat bukti petunjuk bentukan jaksa di dalam pembelaannya, dengan menggunakan argumentasi dan alasan yuridis dan logis, tidak merupakan alasan yang asal kena.

Alasan yang asal-asalan tentu akan merendahkan dan menjatuhkan kredibilitasnya sendiri sebagai seorang advokat. Apakah bisa menggunakan alat bukti keterangan ahli untuk membentuk alat bukti petunjuk, Apabila dalam Pasal 188 ayat 2 telah ditentukan secara limitatif, apalagi dengan menggunakan kata "hanya", maka sudah pasti tidak diperkenankan hakim menggunakan alat bukti keterangan ahli untuk membentuk alat bukti petunjuk. Namun, keterangan ahli dapat digunakan untuk tambahan bahan dalam membentuk alat bukti petunjuk. Sama halnya dengan barang bukti, yang juga dapat digunakan sebagai bahan tambahan untuk membentuk alat bukti petunjuk.

\section{Cara-cara Mendapatkan Bukti Petunjuk Oleh Jaksa Penuntut Umum}

A.Z. Abidin Farid memberi perumusan tentang asas oportunitas sebagai berikut "Asas hukum yang memberikan wewenang kepada Penuntut Umum untuk menuntut atau tidak menuntut dengan atau tanpa syarat seseorang atau korporasi yang telah mewujudkan delik demi kepentingan hukum.” (A.Z. Abidin Farid, 1981, h. 12)

Proses untuk menentukan suatu berkas perkara guna menentukan lengkap tidaknya berkas perkara tersebut untuk dilimpahkan di persidangan dalam rangkaian proses peradilan pidana terletak pada tahap Prapenuntutan yang menggambarkan adanya keterkaitan antara Penyidik dengan Penuntut Umum. Apabila terdapat kekurangan di dalam berkas perkara, yang nantinya akan menyulitkan Kejaksaan dalam melakukan penuntutan, maka berkas perkara dapat dikembelikan kepada Penyidik untuk disempurnakan dengan disertai petunjuk yang dianggap perlu. 
DE IEGA LATA

Jurnal Ilmu Hukum

FAKULTAS HUKUM UMSU
Käian Tentang Penggunaan...(Pityani Meutia Lubis)

Volume 3 Nomor 2, Juli-Desember 2018, 185-203 DOI: https://doi.org/10.30596/dll.v3i2.3159

Syarat-syarat untuk dapat dijadikan petunjuk sebagai alat bukti haruslah: (Andi Hamzah dan Indra Dahlan, 1984, h. 263)

a. Mempunyai persesuaian atau sama lain atas perbuatan yang terjadi.

b. Keadaan-keadaan perbuatan itu berhubungan satu sama lain dengan sengaja kejahatan yang terjadi berdasarkan pengamatan hakim baik dari keterangan terdakwa maupun saksi di persidangan.

Pada prinsipnya, ketentuan tentang Penyidikan dan Penuntutan dalam KUHAP di atas menunjukkan hubungan yang erat antara penyidikan dengan penuntutan. Secara ringkas dapat dikatakan bahwa penyidikan merupakan kegiatan untuk mengumpulkan alat bukti mengenai adanya satu tindak pidana beserta pelaku tindak pidana tersebut, sementara penuntutan merupakan kegiatan yang ditujukan untuk mempertanggungjawabkan hasil dari kegiatan penyidikan di forum pengadilan.

Oleh karena itu, pelaksanaan dari integrated criminal justice system sebetulnya adalah untuk melaksanakan penegakan hukum yang terpadu dan berkesinambungan untuk mendapatkan out put yang maksimal. Dalam hal ini, penyidikan haruslah diarahkan kepada pembuktian di persidangan, sehingga tersangka (pelaku tindak pidana) dapat dituntut dan diadili di persidangan. Penyidikan yang berakhir dengan putusan (vrisjpraak) ataupun lepas dari segala tuntutan (onslag van alle rechtsvervolging) dari Pengadilan terhadap pelaku tindak pidana akan merugikan masyarakat dan lembaga penegak hukum itu sendiri.

Hal ini merupakan bagian dari kewenangan Kejaksaan sesuai dengan Dominis Litius, yaitu maka penetapan dan pengendalian kebijakan penuntutan hanya berada di satu tangan yaitu Kejaksaan. Sebelum penyidikan dimulai, sudah harus diperkirakan delik yang dan diatur dalam ketentuan perundang-undangan. Hal tersebut sangat penting, karena penyidikan diarahkan kepada keadaan yang terjadi, yang cocok dengan perumusan delik tersebut. Namun demikian, Penuntut Umum dapat pula mengubah pasal perundang-undangan pidana yang dicantumkan oleh Penyidik. Disinilah letak hubungan yang tidak terpisahkan antara penyidik dan Penuntut Umum.

Adapun mekanisme mendapatkan bukti petunjuk oleh Jaksa Penuntut Umum melalui koordinasi dalam hal penyidikan antara Kepolisian (Penyidik) dengan Kejaksaan (Jaksa Penuntut Umum), hal tersebut dilakukan dengan tahap-tahap sebagai berikut:

a. Setelah Kepolisian (Penyidik) melakukan kegiatan penyidikan, maka Kepala Kepolisian di unit bersangkutan (Kapolres/Kapolsek) segera mengirim Surat Pemberitahuan Dimulainya Penyidikan (SPDP) kepada Jaksa Penuntut Umum melalui Kajati/Kajari. Pengiriman SPDP inilah yang merupakan titik awal hubungan koordinasi antara Kepolisian (Penyidik) dengan Kejaksaan (Jaksa Penuntut Umum) dalam hal dilakukannya suatu kegiatan penyidikan.

b. Selanjutnya, Kajati atau Kajari akan menunjuk Jaksa untuk melakukan pemantauan perkembangan penyidikan dan melakukan penelitian berkas perkara (form surat P-16A). 
Jurnal Ilmu Hukum

FAKULTAS HUKUM UMSU
Kajian Tentang Penggunaan...(Pityani Meutia Lubis)

Volume 3 Nomor 2, Juli-Desember 2018, 185-203 DOI: https://doi.org/10.30596/dll.v3i2.3159

Jaksa yang ditunjuk inilah yang akan melakukan koordinasi dengan para penyidik dalam hal menentukan suatu perkara layak atau tidak ditingkatkan dalam tahap penuntutan.

c. Setelah Penyidik selesai melakukan tindakan-tindakan penyidikan, seperti melakukan pemeriksaan terhadap saksi, ahli maupun tersangka, melakukan penyitaan, penangkapan, penahanan dan sebagainya, maka hasil dari kegiatan penyidikan tersebut dituangkan dalam sebuah Berkas Perkara. Selanjutnya Penyidik melimpahkan Berkas perkara tersebut ke Kejaksaan untuk diteliti.

d. Jaksa Peneliti melakukan penelitian berkas perkara, apakah berkas perkara tersebut telah memenuhi syarat formil maupun materiil untuk dilimpahkan ke persidangan. KUHAP menentukan paling lama 7 (tujuh) hari sejak diterimanya Berkas Perkara tersebut, Jaksa sudah harus menyatakan sikap. Dalam hal ini terdapat 2 (dua) sikap dari Jaksa Peneliti, yaitu:

1) Apabila berkas perkara telah dinyatakan lengkap, maka Jaksa Peneliti akan menyusun Berita Acara Pendapat yang menyatakan bahwa Berkas Perkara telah lengkap dan berkas perkara dapat dinaikkan ke tahap penuntutan. Apabila sikap ini yang diambil oleh Jaksa Peneliti, maka penyidikan berarti telah selesai dan tahap Prapenuntutan dengan sendirinya akan beralih ke tahap Penuntutan. Konsekuensi dari peralihan dari tahap Prapenuntutan ke tahap Penuntutan tersebut sekaligus berakibat beralihnya "tanggung jawab yuridis" perkara pidana dari tangan Penyidik ke tangan Penuntut Umum setelah Penyidik menyerahkan tanggung jawab atas tersangka dan barang bukti kepada Penuntut Umum (Pasal 8 ayat 3 huruf b KUHAP). Selain itu Jaksa Peneliti juga segera menyusun Rencana Dakwaan sebagai landasan untuk membuat Surat Dakwaan yang akan dilimpahkan ke Pengadilan.

2) Apabila Berkas Perkara dinyatakan kurang lengkap, maka Jaksa Peneliti akan segera menerbitkan Surat (P-18) yang menyatakan bahwa Berkas Perkara dikembalikan kepada Penyidik, karena berkas tersebut masih kurang lengkap. Selanjutnya dalam waktu 14 (empat belas hari) sejak diterimanya berkas perkara, Jaksa Peneliti sudah harus memberikan petunjuk kepada penyidik, baik berupa kelengkapan syarat formil maupun syarat materiil.

3) Setelah menerima petunjuk dari Jaksa untuk melengkapi berkas perkara, Penyidik "wajib" melengkapi berkas perkara sesuai dengan petunjuk Jaksa. Dalam hal ini, koordinasi juga dilakukan dengan cara Penyidik menghadap kepada Jaksa untuk memperoleh petunjuk secara konkrit dalam melengkapi kekurangan Berkas perkara. Setelah berkas perkara dilengkapi oleh Penyidik, Penyidik dalam waktu 14 hari harus menyerahkan atau menyampaikan kembali berkas dan tambahan hasil penyidikan kepada Penuntut Umum (Pasal 110 ayat 2 dan 3 serta pasal 138 ayat 2 KUHAP).

4) Jaksa Peneliti kembali melakukan penelitian berkas perkara dan setelah dinyatakan lengkap segera memberitahukan kepada penyidik untuk melimpahkan tersangka dengan 
Jurnal Ilmu Hukum

FAKULTAS HUKUM UMSU
Käian Tentang Penggunaan...(Pityani Meutia Lubis)

Volume 3 Nomor 2, Juli-Desember 2018, 185-203 DOI: https://doi.org/10.30596/dll.v3i2.3159

barang bukti kepada Jaksa Penuntut Umum. Namun apabila berkas perkara tersebut ternyata menurut Jaksa Peneliti masih kurang lengkap, maka berkas perkara tersebut dikembalikan lagi kepada Penyidik dan proses bolak-balik berkas perkara tersebut akan terjadi sampai berkas perkara dinyatakan lengkap oleh Jaksa.

\section{Proses Penggunaan Alat Bukti Petunjuk Oleh Jaksa Penuntut Umum Sebagai Sarana Pembuktian Perkara Pencabulan Terhadap Anak}

Djisman Samosir berpendapat bahwa: Penilaian atas kekuatan pembuktian dari suatu petunjuk dalam setiap keadaan tertentu dilakukan oleh hakim dengan arif lagi bijaksana setelah ia mengadakan pemeriksaan dengan penuh kecermatan dan keseksamaan hati nuraninya (C. Djisman Samosir, 1985, h. 90).

Romli Atmasasmita dalam bukunya mengatakan bahwa:

Asas persamaan di muka hakim tidak secara eksplisit tertuang dalam KUHAP, akan tetapi asas ini merupakan bagian yang tak terpisahkan dari KUHAP. Ditempatkannya asas ini sebagai satu kesatuan menunjukan bahwa betapa pentingnya asas ini dalam tata kehidupan Hukum Acara Pidana di Indonesia. (Romli Atmasasmita, 1983, h. 30).

Menurut Hibnu Nugroho menerangkan bahwa; "saksi adalah orang yang memberikan keterangan guna kepentingan penyidikan, penuntutan dan peradilan tentang suatu perkara pidana yang ia dengan sendiri,ia lihat sendiri dan ia alami sendiri" (Hibnu Nugroho, 2010, h. 34). Ketentuan dalam menerapkan alat bukti petunjuk didasarkan pada Pasal 188 ayat 2 KUHAP membatasi kewenangan Jaksa dalam cara memperoleh alat bukti petunjuk. Jaksa Penuntut Umum tidak boleh sesuka hati mencari alat bukti petunjuk dari berbagai sumber. Sumber yang dapat dipergunakan untuk mengkonstruksi alat bukti petunjuk terbatas dari alatalat bukti yang secara limitatif ditentukan dalam Pasal 188 ayat (2) KUHAP, yaitu:

a. Keterangan Saksi.

b. Surat.

c. Keterangan Terdakwa.

Berdasarkan ketiga alat bukti tersebut persesuaian perbuatan, kejadian atau keadaan dapat dicari dan diwujudkan, sehingga alat bukti petunjuk dapat diperoleh. JPU dilarang mencari dan memperoleh alat bukti diluar yang telah ditentukan undang-undang. Keterangan ahli tidak dipergunakan sebagai sumber memperoleh petunjuk, undang-undang tidak memberi penjelasan yang pasti mengapa keterangan ahli tidak dimasukkan dalam pasal tersebut, meski sebenarnya keterangan ahli dalam hal-hal tertentu sangat menolong untuk memperoleh petunjuk. Kemungkinan pembuat undang-undang melarang keterangan ahli sebagai sumber alat bukti petunjuk didasarkan pada pemikiran perlunya membatasi kewenangan hakim mencari alat bukti petunjuk dari sumber yang terlampau luas. Membuktikan dalam arti logis 
Jurnal Ilmu Hukum

FAKULTAS HUKUM UMSU
Kajian Tentang Penggunaan...(Pityani Meutia Lubis)

Volume 3 Nomor 2, Juli-Desember 2018, 185-203 DOI: https://doi.org/10.30596/dll.v3i2.3159

adalah memberi kepastian yang bersifat mutlak atas suatu peristiwa yang sulit dibantah kebenarannya oleh siapa saja, termasuk oleh pihak lawan. Adapun membuktikan dalam arti konvensional adalah membuktikan suatu peristiwa tapi tidak bersifat mutlak (sehingga kepastiannya sangat relatif) (Zainal Asikin, 2017, h. 98).

Di dalam perkara dimaksud, cara JPU menerapkan alat bukti petunjuk didasarkan pada keterangan saksi, keterangan terdakwa, surat yang berupa visum et repertum dan BAP (Berita Acara Pemeriksaan). Bahwa pada intinya cara hakim menerapkan alat bukti petunjuk tidak hanya terbatas pada Pasal 188 ayat 2 KUHAP yang hanya membatasi cara hakim menerapkan alat bukti petunjuk hanya pada keterangan saksi, surat dan keterangan terdakwa saja, tetapi hakim lebih menafsirkan secara luas yaitu alat bukti petunjuk juga dapat diterapkan berdasarkan fakta-fakta yang terungkap dipersidangantermasuk juga keterangan ahli, olah TKP (Tempat Kejadian Perkara) dan barang bukti.

Penerapan alat bukti petunjuk oleh hakim berdasarkan Pasal 188 ayat 1 KUHAP adalah "untuk menandakan bahwa telah terjadi suatu tindak pidana dan mengetahui siapa pelakunya. Penggunaan alat bukti petunjuk tidak hanya untuk memidanakan seseorang tetapi juga dapat membebaskan seseorang dari tuntutan penuntut umum". Hal ini berarti hakim menyimpulkan bahwa penggunaan alat bukti petunjuk oleh hakim berdasarkan Pasal 1881 KUHAP memang telah terjadi tindak pidana tetapi pelakunya belum tentu seseorang yang telah didakwa oleh penuntut umum.

Petunjuk ada bermacam-macam yaitu:

a. Petunjuk dari penyidik; yaitu petunjuk yang digunakan oleh penyidik dalam melakukan penyidikan untuk dapat mengetahui pelaku kejahatan dan untuk menemukan tersangka berdasarkan bukti-bukti yang ditemukan dalam proses penyidikan tersebut.

b. Petunjuk dari penuntut umum; yaitu sebelum melakukan penuntutan, maka penuntut umum harus melimpahkan berkas yang lengkap ke pengadilan, tetapi apabila berkas dari penyidik belum lengkap maka penuntut umum akan memberikan petunjuk kepada penyidik untuk melengkapi berkas tersebut.

c. Petunjuk dari hakim; yaitu petunjuk yang digunakan oleh hakim di sidang pengadilan berdasarkan persesuaian alat-alat bukti yang diajukan dipersidangan dan fakta-fakta yang terungkap dipersidangan untuk memutus suatu perkara.

Cara menerapkan alat bukti petunjuk didasarkan pada sistem pembuktian menurut undang-undang secara negatif (negatief wettelijk) yaitu alat bukti petunjuk diperoleh berdasarkan alat bukti yang telah ada dan berdasarkan keyakinan hakim sehingga hakim dapat memutus suatu perkara. Hal ini juga didasarkan pada Pasal 183 KUHAP yang berbunyi bahwa hakim tidak boleh menjatukan pidana kepada seseorang kecuali apabila dengan sekurang-kurangnya dua alat bukti yang sah ia memperoleh keyakinan bahwa suatu tindak pidana benar-benar terjadi dan bahwa terdakwa yang bersalah melakukannya.

Alat bukti petunjuk diperoleh tentunya dengan syarat tertentu. Syaratnya berupa adanya 
Jurnal Ilmu Hukum

FAKULTAS HUKUM UMSU
Kajian Tentang Penggunaan...(Pityani Meutia Lubis)

Volume 3 Nomor 2, Juli-Desember 2018, 185-203 DOI: https://doi.org/10.30596/dll.v3i2.3159

persesuaian antara keterangan saksi, surat atau terdakwa. Walaupun Kitab Undang-undang Hukum Acara Pidana (KUHAP) tidak memberikan penjelasan secara lengkap mengenai definisi 'persesuaian' yang dimaksud, pada hakikatnya baik akademisi maupun praktisi memberikan pengertian terhadap 'persesuaian' yakni apabila antara keterangan saksi dikaitkan dengan alat bukti lain yaitu surat atau keterangan terdakwa saling memiliki keterkaitan yang pada akhirnya mengarah pada suatu tindak pidana yang dilakukan oleh terdakwa. Misalnya apabila antara keterangan yang diberikan saksi korban sesuai dengan visum et repertum yang menguatkan, keterangan saksi lainnya juga mengarah pada kronologis sebagaimana didakwakan oleh penuntut umum, maka persesuaian antar alat bukti tersebut dapat menjadi dasar diperolehnya alat bukti petunjuk.

Di dalam pembuktian persidangan pidana, alat bukti petunjuk memiliki kekuatan hukum yang bebas. Hal ini tidak lepas dari sifat alat bukti petunjuk itu sendiri sebagai alat bukti tidak langsung yang tidak dapat berdiri sendiri tetapi harus diperoleh dari persesuaian antara alat bukti lainnya. Oleh karenanya, hakim bebas memberikan penilaian berdasarkan pemeriksaan yang dilakukan dalam tahap pembuktian, selain itu hakim juga memiliki kebebasan untuk mempergunakan alat bukti petunjuk tersebut sebagai upaya memenuhi batas minimum pembuktian.

Pembuktian tentang benar tidaknya terdakwa melakukan perbuatan yang didakwakan, merupakan bagian yang terpenting acara pidana. Dalam hal ini pun hak asasi manusia dipertaruhkan, sehingga bagaimana akibatnya jika seseorang yang didakwa dinyatakan terbukti melakukan perbuatan yang didakwakan akan tetapi hal tersebut tidak benar. Untuk inilah hukum acara pidana berusaha mencari kebenaran materiil.

Pembuktian juga merupakan titik sentral hukum acara pidana. Pembuktian adalah ketentuan-ketentuan yang berisi penggarisan dan pedoman tentang cara-cara yang dibenarkan Undang-Undang membuktikan kesalahan yang didakwakan kepada terdakwa. Pembuktian juga merupakan ketentuan yang mengatur alat-alat bukti yang dibenarkan undang-undang yang boleh dipergunakan hakim membuktikan kesalahan yang didakwakan. Persidangan pengadilan tidak boleh sesuka hati dan semena-mena membuktikan kesalahan terdakwa (M. Yahya Harahap. 2018: 273).

Alat bukti tersebut di atas memenuhi rumusan minimum pembuktian dan memperoleh keyakinan bahwa terdakwa terbukti bersalah melakukan tindak dengan sengaja melakukan persetubuhan terhadap anak dibawah umur. Aturan mengenai pembuktian saksi terdapat dalam Pasal 185 ayat 1 sampai 7 KUHAP. Keterangan saksi yang dimaksud dalam Pasal 184 Undang-Undang Nomor 8 Tahun 1981 tentang Hukum Acara Pidana (KUHAP) ini adalah "saksi sebagai alat bukti yang dihadirkan dalam sidang pengadilan agar hakim dapat menilai keterangan-keterangan saksi itu, yang ditinjau dari sudut dapat atau tidak dipercaya, berdasarkan tinjauan terhadap pribadi, gerak geriknya dan yang lain-lain".

Saksi yang dihadirkan dalam persidangan nantinya akan disumpah agar mempunyai 
Jurnal Ilmu Hukum FAKULTAS HUKUM UMSU
Kajian Tentang Penggunaan...(Pityani Meutia Lubis) DOI: https://doi.org/10.30596/dll.v3i2.3159

kekuatan pembuktian yang kuat dan nantinya dapat dijadikan pertimbangan hakim dalam memutus suatu perkara pidana. Disebutkan dalam Pasal 160 ayat 3 Undang-Undang Nomor 8 Tahun 1981 tentang Hukum Acara Pidana (KUHAP) bahwa "saksi wajib untuk disumpah atau janji dalam setiap akan dimintai keterangannya di persidangan sesuai dengan agamanya masing-masing".

Kemudian lafal sumpah atau yang diucapkan berisi bahwa saksi akan memberikan keterangan yang sebenar-benarnya dan tidak lain dari yang sebenarnya yang dilakukan sebelum saksi memberikan keterangannya dalam persidangan dan jika dalam keadaan perlu oleh hakim pengadilan sumpah atau janji ini dapat diucapkan sesudah saksi memberikan keterangannya sesuai dengan Pasal 160 ayat 4 Undang-Undang Nomor 8 Tahun 1981 tentang Hukum Acara Pidana (KUHAP). Jika saksi yang dihadirkan tidak disumpah karena permintaan sendiri atau pihak yang lain tidak bersedia saksi untuk disumpah karena saksi ditakutkan akan berpihak pada salah satu pihak, maka keterangan dari saksi tersebut tetap digunakan, akan tetapi sifatnya hanya digunakan sebagai tambahan alat bukti sah yang lain. Selain itu saksi yang karena jabatannya tidak dapat menjadi saksi akan tetapi mereka tetap bersedia menjadi saksi maka dapat diperiksa oleh hakim akan tetapi tidak disumpah karena itu merupakan perkecualian relatif karena menyimpan rahasia jabatan.

Saksi yang dihadirkan diharapkan sudah dewasa sehingga keterangannya bisa dipercaya dan dapat dipertanggungjawabkan. Saksi yang menolak mengucapkan sumpah atau janji didepan pengadilan saat akan diambil keterangannya tanpa suatu alasan yang sah maka saksi tersebut dapat dikenakan sandera yang didasarkan penetapan hakim ketua sidang, paling lama penyanderaan adalah empat belas hari (Pasal 161 Undang-Undang Nomor 8 Tahun 1981 tentang Hukum Acara Pidana). Pengertian umum keterangan saksi ada dalam Pasal 1 butir 27 Undang-Undang Nomor 8 Tahun 1981 tentang Hukum Acara Pidana (KUHAP), yang merumuskan sebagai berikut "Keterangan saksi adalah salah satu alat bukti dalam perkara pidana yang berupa keterangan dari saksi mengenai suatu peristiwa pidana yang ia dengar sendiri, ia lihat sendiri dan ia alami sendiri dengan menyebut alasan dari pengetahuannya itu".

Saksi adalah orang yang memberikan keterangan guna kepentingan penyidikan, penuntutan dan peradilan tentang suatu perkara pidana yang ia dengan sendiri,ia lihat sendiri dan ia alami sendiri". Ditinjau dari segi nilai dan kekuatan pembuktian atau 'the degree of evidence' keterangan saksi, agar keterangan saksi atau kesaksian mempunyai nilai serta kekuatan pembuktian, perlu diperhatikan beberapa syarat- syarat yang harus dipenuhi oleh seorang saksi, yaitu sebagai berikut;

a. Harus mengucapkan sumpah atau janji

b. Keterangan saksi yang bernilai sebagi alat bukti.

Keterangan saksi yang mempunyai nilai ialah keterangan yang sesuai dengan apa yang dijelaskan Pasal 1 angka 27 KUHAP: (M. Yahya Harahap. 2018, h. 273).

a. Yang saksi lihat sendiri 
Kajian Tentang Penggunaan...(Pityani Meutia Lubis) DOI: https://doi.org/10.30596/dll.v3i2.3159

b. Saksi dengan sendiri

c. Saksi alami sendiri

d. Serta menyebut alasan dari pengetahuan itu

e. Keterangan saksi harus diberikan disidang pengadilan

Bahwa dengan demikian kesaksian yang didengar dari orang lain atau biasa disebut dengan 'testimonium de auditu' bukan merupakan keterangan saksi. Begitu pula pendapat maupun rekaan yang diperoleh dari hasil pemikiran saja bukan merupakan keterangan saksi (Pasal 185 ayat (5) Undang-Undang Nomor 8 Tahun 1981 tentang Hukum Acara Pidana).

Berdasarkan penegasan rumusan Pasal 1 butir 27 Undang-Undang Nomor 8 Tahun 1981 tentang Hukum Acara Pidana (KUHAP), dihubungkan dengan Pasal 135 ayat 1 UndangUndang Nomor 8 Tahun 1981 tentang Hukum Acara Pidana (KUHAP), Pidana dapat ditarik kesimpulan sebagai berikut: (M. Yahya Harahap. 2018, h. 273).

a. Setiap keterangan saksi di luar dari yang didengarnya sendiri dalam peristiwa pidana yang terjadi atau di luar dari yang dilihat dan dialaminya dalam peristiwa pidana yang terjadi, keterangan yang diberikan di luar pendengaran, penglihatan atau pengalaman sadar mengenai suatu peristiwa pidana terjadi, tidak dapat dijadikan dan dinilai sebagai alat bukti. Keterangan semacam ini tidak memiliki kekuatan nilai pembuktian.

b. Testimonium de auditu keterangan saksi yang diperoleh sebagai hasil pendengarannya dari orang lain, tidak mempunyai nilai sebagai alat bukti. Keterangan saksi di sidang pengadilan berupa keterangan ulang dari yang didengarnva dari orang lain, keterangan saksi seperti ini tidak dapat dianggap sebagai alat bukti.

c. Pendapat atau rekaan yang saksi peroleh dari pemikiran bukan merupakan keterangan. Penegasan ini sesuai dengan ketentuan Pasal 185 ayat 5 Kitab Undangundang Hukum Acara Pidana. Oleh karena itu setiap keterangan saksi yang bersifat pendapat atau hasil pemikiran saksi harus dikesampingkan dari pernbuktian dalam membuktikan kesalahan terdakwa. Keterangan yang bersifat dan berwarna pendapat dan pemikiran pribadi saksi tidak dapat dinilai sebagai alat bukti.

Pasal 171 Undang-Undang Nomor 8 Tahun 1981 tentang Hukum Acara Pidana (KUHAP) ditentukan saksi yang tidak disumpah yaitu:

a. Anak yang umurnya belum cukup lima belas tahun dan belum pernah kawin;

b. Orang sakit ingatan atau sakit jiwa meskipun ingatannya baik kembali.

Di dalam penjelasan pasal tersebut dikatakan bahwa anak yang belum berumur lima belas tahun, demikian juga orang yang sakit ingatan, sakit jiwa, sakit gila meskipun kadangkadang saja, yang dalam ilmu penyakit jiwa disebut psychopaat, mereka ini tidak dapat dipertanggungjawabkan secara sempurna dalam hukum pidana maka mereka tidak dapat diambil sumpah atau janji dalam memberikan keterangan, karena itu keterangan mereka hanya dipakai sebagai petunjuk saja.

Keterangan saksi agar menjadi kuat maka harus dihadirkan saksi lebih dari seorang dan 
Jurnal Ilmu Hukum FAKULTAS HUKUM UMSU
Kajian Tentang Penggunaan...(Pityani Meutia Lubis) DOI: https://doi.org/10.30596/dll.v3i2.3159

minimal ada dua alat bukti karena keterangan dari seorang saksi saja tanpa ada alat bukti yang lain tidak cukup membuktikan bahwa terdakwa benar-benar bersalah terhadap dakwaan yang didakwakan kepadanya (unus testis nullus testis). Dalam hal terdakwa memberikan keterangan yang mengakui kesalahan yang didakwakan kepadanya, keterangan seorang saksi sudah cukup untuk membuktikan kesalahan terdakwa, karena disamping keterangan saksi tunggal itu, telah terpenuhi ketentuan minimum pembuktian dan the degree of evidence yakni keterangan saksi ditambah dengan alat bukti keterangan terdakwa. Dengan ini dapat disimpulkan bahwa persyaratan yang dikehendaki Pasal 185 ayat 2 adalah: (M. Yahya Harahap. 2018, h. 288)

a. Untuk dapat membuktikan kesalahan terdakwa paling sedikit harus didukung oleh dua orang saksi

b. Atau kalau saksi yang ada hanya terdiri dari seorang saja maka kesaksian tunggal itu harus dicukupi atau ditambah dengan salah satu alat bukti yang lain

Beberapa syarat bagi saksi agar kesaksiannya tersebut dipakai sebagai alat bukti, diantaranya yaitu:

a. Syarat formal. Bahwa keterangan saksi dapat dianggap sah, apabila keterangan itu diberikan dibawah sumpah

b. Syarat materiilBahwa keterangan seorang saksi saja tidak dapat dianggap sah sebagai alat pembuktian, akan tetapi keterangan seorang saksi adalah cukup untuk alat pembuktian untuk suatu kejahatan yang dituduhkan dan keterangan saksi tersebut adalah yang dia lihat, dia dengar serta dialamainya sendiri.

Keterangan saksi dapat dinilai sebagai alat bukti, keterangan itu harus dinyatakan disidang pengadilan, hal ini sesuai dengan penjelasan Pasal 185 ayat 1 "keterangan saksi yang berisi penjelasan tentang apa yang didengar sendiri, dilihatnya sendiri atau dialaminya sendiri mengenai suatu peristiwa pidana, baru dapat bernilai sebagai alat bukti apabila keterangan itu saksi nyatakan disidang pengadilan".

a. Keterangan seorang saksi saja dianggap tidak cukup.

Bertitik tolak dari ketentuan Pasal 185 ayat 2 KUHAP, keterangan seorang saksi saja belum dapat diambil sebagai alat bukti yang cukup untuk membuktikan kesalahan terdakwa atau 'unnus testis nullus testis'. Ini berarti jika alat bukti yang dikemukakan penuntut umum hanya terdiri dari seorang saksi tanpa ditambah dengan keterangan saksi yang lain atau alat bukti yang lain, kesaksian tunggal yang seperti ini tidak dapat dinilai sebagai alat bukti yang cukup untuk membuktikan kesalahan terdakwa sehubungan dengan tindak pidana yang didakwakan kepadanya, memperhatikan uraian diatas dapat ditarik kesimpulan, bahwa persyaratan yang dikehendaki oleh Pasal 185 ayat 2 KUHAP, yaitu:

a. Untuk dapat membuktikan kesalahan terdakwa paling sedikit harus didukung oleh dua orang saksi; 
Jurnal Ilmu Hukum

FAKULTAS HUKUM UMSU
Kajian Tentang Penggunaan...(Pityani Meutia Lubis) DOI: https://doi.org/10.30596/dll.v3i2.3159

b. Atau saksi yang ada hanya terdiri dari seorang saja maka kesaksian tunggal harus dicukupi atau ditambah dengan salah satu alat bukti yang lain.

c. Keterangan beberapa saksi yang berdiri sendiri.

Dapat dilihat pada Putusan Mahkamah Agung tanggal 17-4-1987, No $28 \mathrm{~K} / \mathrm{Kr}$./1977 yang menegaskan bahwa keterangan saksi satu saja, sedang terdakwa memungkiri kejahatan yang dituduhkan kepadanya dan keterangan saksi-saksi lainya tidak memberi petunjuk terhadap kejahatan yang dituduhkan, belum dapat dianggap cukup membuktikan kesalahan terdakwa, disinilah dituntut kemampuan dari keterampilan penyidik untuk mempersiapkan dan menyediakan saksi-saksi yang secara kualitatif dapat memberikan keterangan yang saling berhubungan, hal seperti itu ditegaskan dalam Pasal 185 ayat 4 KUHAP yaitu;

a. Keterangan beberapa saksi yang berdiri sendiri tentang suatu kejadian atau keadaan dapat digunakan sebagai alat bukti yang sah, dengan syarat;

b. Apabila keterangan saksi itu ada hubunganya satu dengan yang lain sedemikian rupa, sehingga dapat membenarkan adanya suatu kejadian atau keadaan tertentu.

Keterangan saksi korban dalam perkara ini menerangkan bahwa korban di paksa untuk melakukan persetubuhan dengan terdakwa sebanyak dua kali, anak korban mengetahui barang bukti yang dihadirkan di persidangan dan anak korban menyatakan bahwa anak korban mengetahui wajah terdakwa.

\section{KESIMPULAN DAN SARAN Kesimpulan}

Dasar hukum penggunaan alat bukti petunjuk oleh jaksa penuntut umum sebagai sarana pembuktian perkara pencabulan terhadap anak dapat dilihat menurut KUHAP Pasal 188 Ayat (1). Berbicara tentang alat bukti petunjuk itu sendiri mengenai pengertiannya dapat dilihat menurut KUHAP Pasal 188 Ayat 1 "Petunjuk adalah perbuatan, kejadian atau keadaan, yang karena persesuaiannya, baik antara yang satu dengan yang lain, maupun dengan tindak pidana itu sendiri, menandakan telah terjadi suatu tindak pidana dan siapa pelakunya".

Proses penggunaan alat bukti petunjuk oleh jaksa penuntut umum sebagai sarana pembuktian perkara pencabulan terhadap anak Ketentuan dalam menerapkan alat bukti petunjuk didasarkan pada Pasal 188 ayat 2 KUHAP membatasi kewenangan Jaksa dalam cara memperoleh alat bukti petunjuk. Jaksa Penuntut Umum tidak boleh sesuka hati mencari alat bukti petunjuk dari berbagai sumber. Sumber yang dapat dipergunakan untuk mengkonstruksi alat bukti petunjuk terbatas dari alat-alat bukti yang secara limitatif ditentukan dalam Pasal 188 ayat 2 KUHAP, yaitu Keterangan Saksi, surat, dan keterangan Terdakwa.

\section{Saran}

Di dalam penanganan perkara pencabulan Jaksa Penuntut Umum (JPU) dituntut untuk lebih cermat terutama dalam hal penggunaan alat bukti petunjuk, karena selain menyangkut substansi hukum dalam hal ini mengenai menjadikan alat bukti memiliki kekuatan 
pembuktian yang cukup memadai untuk menjerat terdakwa tindak pidana pencabulan. Untuk itulah sebelum menentukan unsur-unsur dalam fakta persidangan, seorang penuntut umum juga harus melihat aspek-aspek lain seperti aspek sosiologis dan psikologis.

Kedudukan Jaksa sebagai aparat hukum diharapkan kritis dalam menyikapi dan menangani perkara. Landasan keadilan harus dijadikan sebuah dogmatis bagi jaksa dalam kinerjanya. Hal ini merupakan sebuah tanggung jawab yang diemban seperti ketika sumpah jabatan. Karena realita yang ada sekarang justru keadilan yang diharapkan mengayomi para aparat penegak hukum semakin jauh dari harapan. 
Jurnal Ilmu Hukum

FAKULTAS HUKUM UMSU
Käian Tentang Penggunaan...(Pityani Meutia Lubis)

Volume 3 Nomor 2, Juli-Desember 2018, 185-203 DOI: https://doi.org/10.30596/dll.v3i2.3159

\section{DAFTAR PUSTAKA}

Atmasasmita, Romli. (1983). Bunga Rampai Hukum Acara Pidana. Jakarta: Bina Cipta.

Atmasasmita, Romli. (1995). Kapita Selekta Hukum Pidana dan Kriminologi. Bandung: Mandar Maju.

Dirdjosisworo, Soedjono. (1983). Pengantar Ilmu Hukum. Jakarta: Rajawali Pers.

Farid, Abidin, A.Z. (1981). Sejarah dan Perkembangan Asas Opportunitas di Indonesia. Ujung Pandang: UNHAS.

Hamzah, Andi. (2014). Hukum Acara Pidana Indonesia. Jakarta: Sinar Grafika.

Hamzah, Andi., \& Dahlan, Indra. (1984). Perbandingan KUHP, HIR dan Komentar. Jakarta: Ghalia. Indonesia.

Harahap, M Yahya. (2001). Pembahasan Permasalahan dan Penerapan KUHAP Penyelidikan dan Penuntutan. Jakarta: Sinar Grafika.

Harahap, M. Yahya. (2007). Pembahasan Permasalahan Dan Penerapan KUHAP (Pemeriksaan Sidang Pengadilan), Banding, Kasasi, dan Peninjauan Kembali. Jakarta : Sinar Grafika.

Harahap, M. Yahya. (2018). Pembahasan Permasalahan dan Penerapan KUHAP. Jakarta: Sinar Grafika.

Lamintang, P.A.F. (1997). Dasar-dasar Hukum Pidana Indonesia. Bandung: Citra Aditya Bakti.

Marzuki, Peter Mahmud. (2011). Penelitian Hukum, Jakarta: Kencana Prenada Media Group.

Nugroho, Hibnu. (2010). Bunga Rampai Penegakan Hukum di Indonesia. Semarang: Badan Penerbit Undip.

Samosir, Djisman C. (1985). Jaksa dan Hakim dalam Proses Pidana. Bandung: Binacipta.

Seokanto, Sorejono., \& Muji, Sri. (1996). Pengantar Penelitian Hukum. Jakarta: UI Press.

Seokanto, Sorejono., \& Muji, Sri. (2003). Penelitian Hukum Normatif Suatu Tinjauan Singkat, Jakarta: Rajawali Pers.

Undang-Undang Nomor 1 Tahun 1946 tentang Kitab Undang-Undang Hukum Pidana (KUHP).

Undang-Undang Nomor 23 Tahun 2002 Tentang Perlindungan Anak.

Undang-Undang Nomor 3 Tahun 1997 Tentang Pengadilan Anak.

Undang-Undang Nomor 8 Tahun 1981 tentang Kitab Undang-Undang Hukum Acara Pidana (KUHAP). 